\title{
JAMES WHITTLE, CHARTIST EDITOR
}

\author{
BY LOWELL L. BLAISDELL \\ Mr. Blaisdell teaches history at Texas Tech University
}

I.

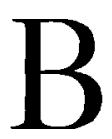

$\mathrm{Y}$ today much is known about Chartism, its influence, numbers, regional manifestations, and personalities. Of the latter, a quantity of studies, both at book and article length, have come forth, including many very good ones in recent years. ${ }^{1}$ One leader who hitherto has received no special treatment, probably because so little is known about him, is James Whittle. In the I830s Whittle was an important figure, serving as editor of three different papers, and playing a prominent part in the 1839 convention.

If one were curious about Whittle and consulted several of the standard works on Chartism, he would quickly notice several references in contexts suggesting that he had some measure of importance, only to discover that he disappears from the pages after a comment or two on his role in the 1839 convention. References may be made to his having been delegate from Liverpool, to his editing the younger Cobbetts' The Champion, or to his attitude at the convention as being that of a "moral force" Chartist. There the information runs out." The reader's questions as to what constituted his overall views, how he acquired them, what kind of personality he had, and what became of him after the convention are left unanswered.

Why is so little known about James Whittle? The largest reason is that in the case of unfamiliar people who lived before the compilation of systematic records by government bureaus, the absence of a death date all but precludes investigation. Obituaries are essential as

${ }^{1}$ See, for instance, A. R. Schoyen, The Chartist Challenge (London, 1958); Donald Read and Eric Glasgow, Feargus O'Connor, Irishman and Chartist (London, 1961); Alfred Plummer, Bronterre (Toronto, 1971); Brian Harrison and Patricia Hollis, 'Chartism, Liberalism and the Life of Robert Lowery', English Historical Review, LXXXII (1967), 503-535.

${ }^{2}$ See R. G. Gammage, History of the Chartist Movement, ${ }_{1} 8_{37-18} 84$, 2nd ed. (New York, 1969), 68. Mark Hovell, The Chartist Movement (London, I918), iा 1, 150; Julius West, A History of the Chartist Movement (London, 1920), 1 12, 122. J. T. Ward, Chartism (London, 1973), 106-107, 117. More recent works, such as G.D.H. Cole, Chartist Portraits (2nd ed., N.Y., 1965), Asa Briggs, ed., Chartist Studies (London, 1959), Dorothy Thompson, The Early Chartists (Columbia, S.C., 1971), and David Jones, Chartism and the Chartists (London, 1975) make no mention of Whittle. 
the means to begin reconstruction of a person's life. As it happens, Whittle's is difficult to come by. ${ }^{3}$ Because in the nineteenth century many people had exactly his name, first and last, he is doubly difficult to locate. ${ }^{*}$ Other complications include such facts as his having been Irish, not English, born, and having died on the Isle of Man, where statistics are kept separate from England's.

There are other reasons for Whittle's comparative obscurity. Because he moved about frequently between England and Ireland, he did not gain easy recognition through identification with a generally familiar place or organization. Furthermore, Whittle, unlike the more colorful Chartists, did not have the knack of drawing sustained attention to himself, hence was easily overlooked. His comparative inconspicuousness was accentuated by a tendency to be quite reticent about his personal life. Then, too, he withdrew completely from Chartism after I 840 . As a result, he was more easily forgotten than personalities who stayed active until I 848 and after, or who became active in the I 840's. A final factor contributing to his haziness as a historical figure is that there are several minor ambiguities concerning the dates of changes in residence and job accessions. Due to these, he would all but disappear from the news before resurfacing in a different locus.

At the time of Whittle's death, only a few English and no Irish, newspapers made reference to his demise. ${ }^{5}$ Of the English ones, only a handful remarked on his passing, offering only a death date and/or an age estimate. ${ }^{6}$ There was one exception. The Manchester Guardian carried, not an obituary, but an unsigned fragmentary reminiscence. Using this item in conjunction with his known age at death, and fleeting references to his personal life made in his journalistic writings, it is possible to piece together his origins and education with a fairly high probability of accuracy. On the death certificate the age at decease was listed as seventy-three. The memorialist in the Guardian referred to his "high education." It seems likely, then, that he is the James Whittle

${ }^{3}$ For instance, Whittle's name does not appear in the obituaries of the London Times, Gentlemen's Magazine, Dictionary of National Biography, Modern English Biography, Men of the Time, and Who Was Who.

${ }^{4}$ In the card catalogue of Chetham Library, Manchester, a slightly erroneous death date is given, which sets the seeker on the right path.

${ }^{5}$ Among those having nothing were the Manchester Examiner and Times, Manchester Courier and Lancashire General Advertiser, Liverpool Daily Post, Dublin Daily Express, Dublin Evening Post, Irish Echo, and Belfast Evening Standard.

${ }^{6}$ These were the Liverpool Daily Courier, Liverpool Evening Express, Manchester City Times, Belfast Morning News, and the Isle of Man Times and General Advertiser, I 7 January, 1874 .

72 I January 1874. 
listed in Alumni Dublinses as son of James Whittle, birthplace, County Antrim, entered Trinity College, aged seventeen, in I8I8, and graduated in $1823 .^{8}$ One of Whittle's own journalistic references makes it evident that he was not a Roman Catholic, although to what Protestant denomination he belonged is not clear. ${ }^{9}$ Whether he ever married and had children does not appear, but surface indications suggest that he did not.

In the dozen or so years from about I 820 until the early i 830 s Whittle resided at different times in the Ireland-Liverpool-Manchester configuration. After a first sojourn at Liverpool he departed, probably for Ireland, returning after a half dozen years in about 1826 or 1827 . In politics he had by this time become a radical. A few years laterI 829-30-he moved over to Manchester. His public association with radicalism and, a little later, Chartism, had its inception at the beginning of 1830 when he became editor of the weekly Manchester and Selford Advertiser. ${ }^{10}$ Like several other emerging radicals of his day, he attained an office with which to influence public opinion at an early age.

\section{II.}

If the ideas, opinions, and prejudices of William Cobbett may be construed to be a political philosophy, then James Whittle is memorable as a fervent Cobbettite. Through reading the Political Register he had become an admirer of Cobbett by the time of his residency in Liverpool in the later I 820 . When a friend introduced him to the elderly curmudgeon at Manchester in February I831, his adulation increased. Such was his admiration that when the Whigs introduced their Lio Reform Bill shortly after, he credited the comparative liberality of the measure to Cobbett's demand, in the 26 February Political Register,

\footnotetext{
${ }^{8}$ Ibid.; copy of death date, General Registry, Isle of Man, to author, 27 August 1975; Alumni Dublinses, A Register of the Students, Graduates, Professors, and Provosts of Trinity College in the University of Dublin (1593-1860) (Dublin, 1935), 877. See also $A$ Catalogue of Graduates Who Have Proceeded to Degrees in the University of Dublin (Dublin, 1867), 607; The Tribune (Dublin) 21 June 1834; The Champion (London), I September I 839 . That Whittle was born in County Antrim in 1801 cannot be ascertained with absolute certainty because the civil authority in Ireland did not record births before I July 1864 -Custom House, Dublin, to author, io September 1975 .

${ }^{9}$ The Champion, I September 1839.

${ }^{10}$ Manchester and Selford Advertiser, 2 June 1832; Northern Star, 29 December I 838 ; The Champion, 30 December 1838 .
} 
for drastic political change. ${ }^{11}$ In Whittle's Cobbettism were such articles of faith as belief in a parliamentary late medieval people's kingdom, the right to bear arms in self-defense, law and justice enforcement left to popular local sheriffs, and the fundamental good sense of the average English common man. ${ }^{12}$ As for the political goals of his own age, Whittle believed in the standard universal suffrage-oriented reform program advocated by radical leaders from Major John Cartwright in the late eighteenth century to Cobbett and Henry Hunt in the post-Waterloo years. As regards the two major parties, toward the Whigs he felt an abiding distrust, seeing them as fake reformers, while as for the Tories, he occasionally felt a trace of longing, faintly hoping that they might perceive the necessity of social reform. In respect to prominent issues of the I 830's, he slightly favored repeal of the Corn Laws and vehemently opposed the New Poor Law. He understood that slavery in the colonies was a social evil, but saw the wage slavery of the Midlands factory workers as a more pressing injustice. Consequently, he gave immediate primacy to the factory measure originally introduced by Michael Sadler. ${ }^{13}$

As his attitude on the latter questions suggests, Whittle was not blind to the problems created by the new industrialism. On the whole, however, Whittle's outlook, like his mentor's, was somewhat restricted. Finding the new phenomenon uncongenial, he desired rather to wish it away than to search at its roots for remedies to the prevailing evils. To him, industry was a false god. Before long other countries would be able to produce the new goods as well as England. The English economy would be depressed by the resultant competition-a condition which, in his opinion, came to pass in $1837-39$. His preference was for rural England of bygone times. ${ }^{14}$ Consequently, his ideas on reform, like those of several other early Chartist leaders, were too narrowly focused, and had a certain anachronistic flavor to them.

In personality, the traits of candor, pugnacity, impetuosity, and idealism preponderated in James Whittle. As an instance of the latter two, in the summer of I 830 he used the occasion of one of the first trips by train on the Manchester and Liverpool Railway to distribute hun-

${ }^{11}$ Manchester and Selford Advertiser, 2 June 1832 ; The Tribune, 6 September 1834.

12 The Champion, 18 , 31 March i 839.

${ }^{13}$ Manchester and Selford Advertiser, I9 March, I6 April, I4 May, 9 July, ro September, I7 December, I831, 28 January, 3 March, 18 August, I5 December, 1832. The Champion, 2 October, 1837 ; 26 May 1838 .

${ }_{14}$ Manchester and Selford Advertiser, Io September I831; The Champion, 24 February 1839 . 
dreds of tricolour flags in celebration of the recently concluded July Revolution in France. ${ }^{15}$ Probably some of the subscribers found this ultra-democratic gesture to be obtrusive. As for his frankness and fighting spirit, these showed up in the forthrightness with which he discussed controversial issues. When he felt it necessary, he would make unflattering references to prominent personages, or involve himself in journalistic combat with others.

As a journalist Whittle was well above average. To him, a newspaper needed to do more than merely record the news passively. Accordingly, the three with which he was associated had editorial verve as the center piece of a general crusading bent. Both the editorials and the news columns of his papers featured unusually extensive and accurate political information. As for his limitations, one was that his style left something to be desired. Occasional opacity and prolixity characterized it. Another was that his combativeness led him to oversimplify opponents' viewpoints. Also, when occasionally he incorrectly jumped to a conclusion, he showed a reluctance to admit it.

III.

Against such a backdrop, it is Whittle's actions and activities from the time of his first editorship through the Chartist convention of I 839 that gives importance to his outlook and career. At the time he was Advertiser editor, the Reform Bill was the great issue. This measure he ardently supported, just as did the general public and most of the midlands workers. In his mind, its passage, in the face of aristocratic opposition, would prove that major political reform was achievable. ${ }^{16}$ Optimistically, he also felt confident that passage of the Reform Bill soon would result in enfranchisement of the working class. That end would be assured by the resultant vastly liberalized Commons. ${ }^{17}$ Given this conviction, when he spotted Henry Hunt, the M.P. from Preston, resorting to a tactic of nominally supporting the bill in Commons, only to denounce it in speeches before the working class public, he castigated the Orator for his duplicity. ${ }^{18}$

The Reform Bill having become law, the Advertiser strongly supported Cobbett and John Fielden in their efforts to be elected M.P.'s

\footnotetext{
15 Manchester Guardian, 21 January 1874.

${ }_{16}^{16}$ Manchester and Selford $A$ dwertiser, I4 May I831.

${ }_{17}$ Manchester and Selford Advertiser, 16 April, I4 May 1831.

${ }^{18}$ Ibid., I 5 April, 7 May 1831, 2 June 1832.
} 
from Oldham. In some degree, the newspaper's support probably contributed to their victory. ${ }^{19}$ An interesting sidelight was Whittle's own entry as token candidate at Wigan. This produced a revealing insight into Whittle's financial standing, when at one point he mentioned that even under the new liberalized suffrage law his income was not sufficient to qualify him as a voter. In comparison with the paired winners' totals of 302 and 296 votes respectively, he garnered only twelve. ${ }^{20}$

Meantime, many hackles had been raised by Whittle's vigorous editorials. For instance, the Advertiser's stands brought criticism from the influential Archibald Prentice, editor of the Manchester Times. ${ }^{21}$ Even more damaging, in Manchester, Unitarian business interests were a powerful force, and he fell afoul of them. Whittle remarked that a Unitarian, Mark Philips, one of the victors in the Wigan election, was persecuting both him and the property with which he was associated. ${ }^{22}$ Separately, John Edward Taylor, editor of the Manchester Guardian, and likewise a Unitarian, instituted a libel suit against the Advertiser. ${ }^{23}$ Though Whittle had increased the Advertiser's sales so that even in a slow week they averaged over 3,000 copies, the upshot of so many disputes was his departure from the paper. ${ }^{24}$ It may be safely assumed that this outcome was very disappointing to him. ${ }^{25}$

After a year and a half Whittle obtained another editorial post. In his native Ireland, Patrick O'Higgins, rather well known a few years later as leader of the ill-starred Dublin Chartists, founded a weekly, The Tribune. ${ }^{26}$ During most of its brief existence the Roman Catholic O'Higgins and Protestant Whittle shared proprietorship, with the latter

19 Ibid., I6 July 1831, 14 July 1832; Manchester Guardian, 2 I January 1874.

${ }^{20}$ Manchester and Selford Advertiser, I4 July, I5 December 1832.

${ }^{21}$ Ibid., 24 September 1831, 22 December 1832.

22 Raymond V. Holt, The Unitarian Contribution to Social Progress in England, 2nd ed. (London 1952), 186-187, 193-198, 224; Manchester and Selford Advertiser, 24 September I831, I I February, 25 February, 29 September, 21 October 1832.

${ }^{23}$ Manchester and Selford Advertiser, 29 September, I 832.

${ }^{24}$ Ibid., 7 January 1832 . Judging by this figure, the Advertiser's average circulation may have been $4,000-5,000$. By comparison, when in 1837 Bronterre O'Brien's Bronterre's National Reformer slipped to 4,0oo after three months of existence, it died outAlfred Plummer, Bronterre (Toronto, 1971), 80.

${ }^{25}$ Indications of Whittle's political, if not also his personal, discouragement, appear in the Advertiser 1 5, 22 December 1832. In the 21 January 1874 Manchester Guardian reminiscence, his leaving is attributed to a change in proprietorship. However, this, in turn, likely was caused by his disputations.

${ }^{26}$ Rachel O'Higgins, "Ireland and Chartism," M. A., Thesis, Trinity College, Dublin, 1959, 329. For some data on Patrick O'Higgins, see Rachel O'Higgins, "The Irish Influence in the Chartist Movement," Past and Present, XX (I96I), 83-96, especially 86-88. 
serving as chief editorialist. In the first issue, Whittle announced they were radical reformers. For England, they favored universal suffrage, the secret ballot, and annual parliaments. For Ireland, their immediate primary concern, they advocated Repeal of the Union, disestablishment of the Anglican Church, land reform, and improvement in the quality of officialdom. Whittle added that he felt proud to be an Irishman, regarded this island as his first allegiance, and would give its affairs his close attention. Nevertheless, no matter on which island he happened to find himself, he would stand up for the principles of freedom and the people's rights. ${ }^{27}$

As regards political issues of the year, The Tribune, though giving Daniel O'Connell qualified support, charged him with being willing to compromise with the Whigs so that they might remain in office. On a different subject, unrest in Ireland, it opposed parliament's new Coercion Bill. As for O'Connell's more radical colleague, Feargus O'Connor, it gave him considerable coverage without endorsing him. When in the fall of the year William Cobbett visited the island, The Tribune gave this event the most extensive coverage of any in its short life. ${ }^{28}$ Unfortunately for the proprietors, the paper was unable to build up a clientele. After one number in the first week of 1835 , it went under. ${ }^{29}$

His second editorship having failed, Whittle returned to the Manchester area. Enough had happened since the passage of the Reform Bill for him to have become increasingly disillusioned with the political scene. Contrary to his expectations, working class suffrage had not arrived. Nor was the quality of the Commons membership any higher. In fact, so complete was his distrust of that body that the only M.P.s to whom he ever gave his full confidence were Cobbett-until his death -Fielden, and, in Ireland, Sharman Crawford. With regard to his homeland, the Whigs, as he perceived them, made no effort to alleviate the dire poverty there. The resultant violence they dealt with only by repression.

As these views took shape in his mind, it happened that the means to air them appeared. In I 837 John $M$. and James P. Cobbett, the sons of Whittle's now deceased hero, took over The Champion, a weekly dating from the year before. Before, and especially as part of, the

27 The Tribune, 2 I June I 834 .

${ }^{28}$ Ibid., 28 June, 26 July, 29 August, 6, I 3, 20, 27 September, 4, I I, I 8, 25 October, I, 8 November, 6, 13 December 1834 .

${ }^{29}$ Ibid., 3 January 1835 . 
Cobbett's proprietorship, the Irish-Lancasterman contributed commentary. His political letters were addressed sometimes from Manchester, ${ }^{30}$ sometimes from Dublin. Perhaps he received a stipend for them. In ones concerning Ireland, he backed Patrick O'Higgins in his advocacy of an Irish Poor Law, gave descriptions of extreme family hardship, and denounced O'Connell for his Whig alliance and refusal to damn the government for its Irish policies. As for England, with the New Poor Law then in the process of implementation, he, along with many other northern radicals hit hard at its inequities. In terms of political allegiance, he identified himself with "Honest John" Fielden. As illustration, a dinner was given for the Oldham M.P. in Manchester, June 4, I 838, at which the speakers included the Cobbett brothers, the Rev. J. R. Stephens, and Whittle. Stephens and O'Connor delivered speeches implying that the poor people ought to use force to challenge parliament. To this Fielden replied with reproofs to the two firebrands. Whittle supported Fielden, saying that their words ". . . sounded more the note of despair than one of wise deliberation." ${ }^{\prime 1}$

It was in the second half of 1838 that the Chartist movement for universal suffrage engulfed the Anti-Poor Law agitation, benefitting thereby from the unrest that the earlier movement had aroused. Large, responsive crowds gathered to listen to radical speakers. Torchlight parades added to the excitement until the government ordered them stopped. In the heady atmosphere, a good many Chartists came to the conclusion that through intense group pressure universal suffrage stood a good chance for immediate success. Some leaders, such as O'Connor, Julian Harney, and Bronterre O'Brien, went further. They hinted more or less directly of the use of force to obtain the vote. Others like William Lovett and Thomas Attwood were careful to stress that the movement stood for peaceful means only. ${ }^{32}$ Today, scholars, in assessing the distinction between "physical" and "Moral force" Chartism, tend to hold that the contrast between the two positions has been overemphasized. The differences are accounted for as reflecting considerations of timing, circumstances, and personality. ${ }^{33}$

\footnotetext{
30 The Champion, 18 December $1836 ; 15$ January, 2 October 1837; 19, 26 May, 30 September, 18 November 1838 .

31 Ibid., 9 June 1838 .

${ }^{32}$ Of many useful studies of Chartism, a recent very helpful one is J. T. Ward, Chartism (London, 1973), especially Chapter IV, 86-1 Io.

${ }^{33}$ See especially Asa Briggs, "National Bearings," in Chartist Studies, ed., Asa Briggs (London, 1959), 288-304, and particularly 300-301.
} 
To a limited degree, Whittle's conduct illustrates the present tendency to shrink the distinction. At public gatherings in the fall of 1838 , his natural ardor succumbed to the prevailing mood. Occasionally his remarks seemed to bring him very close to being a physical force Chartist. Actually, his apparent near-identification with the militant wing was partly the result of faulty reporting. In fact, away from the heated climate of successive meetings, his inclination was much closer to moral force Chartism, as is shown by his comments at the Fielden dinner, the long-time association with the Cobbetts, his support of the Reform Bill back in I 83I-32, and, a little after this, his attitude at the Chartist convention.

Whittle was on hand at several of the large autumn meetings. At the famous one on Kersal Moor near Manchester, September 24, he made a brief speech. Almost simultaneously Liverpool Chartists made him their delegate to the approaching convention, probably on the rather flimsy ground that he had resided there almost a decade before. At these and other gatherings he opined that parliaments under the Reform Bill were worse than they had been before 1832 , that the people's righteous wrath had the government in a state of fright, and that the plight of the downtrodden induced in the nation's soldiers an inclination toward the lowly. ${ }^{34}$ Such was his confidence in the popular cause that once at Preston when the flamboyant Feargus O'Connor referred to the people as facing "determined enemies," he corrected him by saying they were only up against "frightened" ones. ${ }^{35}$ In London, at the year's end he denounced Whigs, Tories, and "Sham-Radicals" such as O'Connell, and urged the people to give massive backing to the convention delegates. ${ }^{36}$

In the case of both the Preston and London meetings, Whittle's comments were greatly exaggerated by the Northern Star. According to O'Connor's paper, Whittle made reference at Preston to the need to "hamstring them [the upper class leaders] upon the scaffold." In particular, he threatened Lord Fitzwilliam's life because that aristocrat

${ }^{34}$ The Champion, 30 September, 30 December 1838 . Whittle's platform conduct in this period might be usefully compared with that of Robert Lowery. At the convention a little later Lowery was somewhat more radical than he. Subject to the same audience expectations and fellow-speaker pressures, Lowery had spoken in the fall in about the same vein as Whittle. Brian Harrison and Patricia Hollis, "Chartism, Liberalism and the Life of Robert Lowery," English Historical Review (1967), 503535, especially 513-514.

${ }^{35}$ The Champion, 18 November ${ }_{1838 .}{ }^{36}$ Ibid., 30 December ${ }_{1} 838$. 
recently had made some observations favorable to the New Poor Law. This led the London Globe, in highly disapproving tones, to refer to Whittle as an exponent of force. The latter strongly protested. The Globe then threw it up to him that since his "friend" O'Connor's paper had so quoted him, he must have thus spoken. ${ }^{37}$ Not having read the Northern Star, Whittle had not known of the misquotation. As for the London gathering, the same paper had him saying that 2,500,000 people had signed the charter. This is a figure reading like a typical O'Connor exaggeration rather than a Whittle statement. In The Champion's own account, nothing was said about Whittle having given a figure for the number enrolled. ${ }^{38}$ That he said any such thing is extremely improbable.

IV.

By the time the delegates convened on February 4, I839 Whittle had grown into a figure of some standing. A certain amount of attention had come his way through his part in the autumn get-togethers. Furthermore, he had acquired some prestige through advancement to the editorship of The Champion. Consequently, at the convention he had a rather important part. With regard to this most famous Chartist gathering, much is known about the actions of such prominent militants as O'Connor, O'Brien, and Harney. ${ }^{39}$ On the other hand, the activities of the "moderate" leaders have been less fully explored. Of the latter, the conduct of Lovett, because of his influential position in 1838-39, is most generally known. ${ }^{40}$ As another of the "moral forcers," Whittle's actions thus are interesting to follow.

The most striking feature of Whittle's attitude is that, in contrast to his confident, occasionally even belligerent, mood throughout the fall, from the very beginning of the convention he favored restraint. Though as late as the December meeting he had repeated his conviction that

${ }^{37}$ Northern Star, io November 1838 ; The Champion, 2 December 1838 .

${ }^{38}$ Northern Star, 29 December 1838; The Champion, 30 December 1838 . Incidentally, it is worth noting that Whittle's name appears in the Francis Place Collection, Manuscript Division, British Museum, only once, in connection with the December meeting. This is a clipping from the Northern Star, 29 December 1838 , in which, interestingly, the supposed Whittle estimate of two and a half million signatures is underlined-Add. Mss. 27,280, Ff. 356-358.

${ }^{39}$ See Read and Glasgow, O'Connor, 81-85; Plummer, Bronterre 94-134; Schoyen, The Chartist Challenge, 54-85.

${ }^{40}$ Lovett offered his own account in William Lovett, The Life and Struggles of William Lovett (London, 1876), 201-225. 
the middle class was frightened and the soldiers were on the side of the poor, ${ }^{41}$ only a little more than a month later he perceived matters quite differently. The reasons for the change may be surmised. These likely included the government's successful arrest of Stephens, indications that the common soldiers, after all, were loyal to their superiors, and the knowledge that at the time of the opening of the convention there were only some 500,000 signatures on the charter.

In the early sessions, O'Brien carried a motion inviting parliamentary members to meet with convention members as their co-equals. Whittle opposed, contending that this might lead them into a petty violation of the law, and, more important, could lead to the "danger of public ridicule." ${ }^{\prime 2}$ A little later, when the question of resort to illegality came up, he expressed his opposition, arguing that only in the last extremity and on an issue of principle should they act contrary to law. On the same general theme, in mid-February The Champion proprietor, James P. Cobbett, introduced a tell-tale motion which would have committed the convention not to support law-breaking force, or any other "ulterior measures." A large majority of the convention found this too restrictive, rejecting it 36-6. Among the six was Whittle. ${ }^{43}$ However, unlike Cobbett, who resigned his seat, Whittle stayed on. When, in early March, Julian Harney, William Rider, and Richard Marsden, as a means to pressure the convention, instigated the London Democratic Association to pass threatening resolutions, it was Whittle who presented a motion demanding their apology, on pain of expulsion. In reply, Taylor and Marsden brought up the old Preston meeting allegation, and argued that he permitted violent words for himself, but when others at the convention used them, he objected. ${ }^{44}$ The dispute ended with the culprits apologizing pro forma, so in effect The Champion editor lost. When the convention members, finding that throughout the country Chartism had less support than had been anticipated, decided to send out delegates to drum up greater enthusiasm, Whittle backed this tactic.

${ }^{41}$ Whittle did not equal Lovett in pacifistic outlook. Throughout the autumn, when others were militant, Lovett deplored hints of violence. At the December meeting he criticized the Northern Star and The Champion for printing the militants' threatening speeches-Northern Star, 29 December ${ }_{1} 838$.

42 The Champion, I7 February 1839.

${ }^{43}$ Ibid., I7, 24 February I 839 . At about the same time, on the question of Ireland, Whittle found an issue on which he could agree with O'Connor. He seconded an O'Connor motion to have the convention find means to unite the English and Irish working people-Ibid., 24 February 1839.

${ }^{44}$ Ibid., 10 March I 839 ; Lovett, Life, 204. 
He recommended that the representatives be given the maximum possible opportunity to locate new adherents. ${ }^{45}$

By late April the divisions between viewpoints had deepened. Speculation was rife as to where Chartism might be heading. Among the go-slow faction, there had been a steady trickle of resignations. This led to criticisms of those who withdrew. Whittle defended their right to resign. On the other hand, when, in the wake of the withdrawals, the radicals and O'Connor jammed through Joseph Williams as a replacement, he strongly protested membership-packing. ${ }^{46}$ Early in May the convention reached the point of being ready to present the charter to its two uneasy parliamentary patrons, William Attwood and John Fielden. The M.P.s desired the conventioneers to guarantee that they would in no circumstances use force. This attitude produced criticisms of the M.P.s from the convention floor. To these barbs Whittle responded with a strong defense of Fielden. With his own views fully in accord with his mentor's, more than once he warned against threatening speeches that might set off small uprisings. He was sure that they would only be easily crushed, as had occurred in Ireland in $\mathbf{1 7 9 8 . 4 7}$

By mid-May, the convention, considerably diminished in numbers, had moved from London to more militant Birmingham-a move which Whittle, incidentally, had opposed. At the new location the dwindling delegates immediately voted a resolution in favor of "ulterior measures." Actually, the proposed steps amounted to a considerable comedown from earlier threats, because only various forms of passive resistance were recommended, not force per se. Even this, Whittle found to be too much. In the course of voting against the motion, he announced that he differed "wholly from the propriety of issuing it." $\mathrm{He}$ then submitted his resignation as his final act as a delegate. At a later date, he explained that his withdrawal was because the convention "undertook to give the people advice, and gave them poor advice." ${ }^{48} \mathrm{By}$

${ }_{45}$ The Champion, io March 1839.

${ }^{46}$ Ibid., 28 April I 839 . As indicative of O'Connor's reliability with respect to anything having to do with Whittle, on April 23 he stated that down to that date there were a number of members including Whittle who had appeared at convention sessions only once or twice-West, History of Chartist Movement, 112. At that point The Champion editor had been present at no less than seventeen meetings.

47 The Champion, 10, 3 I March, 5, I 2, May 1839.

${ }^{48}$ Ibid., 5, I 2 May, 20 October 1839 . Incidentally, the Home Office, which-as is well known-kept close tabs on the Chartist leaders who made verbal threats, paid virtually no attention to Whittle, evidently because the officialdom judged him to be pacifistic. In all the reports for I $838-39$, his name-spelled Wittle-appears but once. This was in connection with a proposed meeting at Kersal Moor, Manchester, in the 
comparison, Lovett saw fit to stay through to the end, thereby incurring arrest and incarceration. As for Whittle, as long as he participated he steadily opposed the militants out of the conviction that even the threat of force-and most certainly any attempt to implement it - would result in a costly defeat for Chartism. Worse, the first might easily produce the second. ${ }^{49}$ With his departure, he resumed full-time his editorship of The Champion.

Once the convention broke up in early September, Whittle fell into a bitter quarrel with Feargus O'Connor. The dispute illustrates why many of the moderates so intensely disliked the colorful O'Connor. Several considerations triggered the quarrel. Basic to it was Whittle's distrust of O'Connor going back to his days as an Irish M.P. ${ }^{50}$ As he saw it, O'Connor's actions in 1838-39 confirmed his long-held suspicions. ${ }^{51}$ More particularly, The Champion editor was convinced that O'Connor, by his blustering talk and contradictory actions, contributed greatly to the demoralizing windup of the convention. Worse, by offering at the end to establish another convention with the delegates' expenses paid for out of his own pocket, he was trying to personalize Chartism. ${ }^{52}$ Whittle equally blamed his fellow Irishman for his extravagant promise in the autumn of I 838 that, come what might, the Chartists would obtain the suffrage in no more than a year. Thus in the fall of 1839 this made them the butt of ridicule. ${ }^{53}$ Just at this moment, O'Connor suddenly departed on what turned out to be a month-long trip to Ireland. Whittle, with his wide familiarity with Irish affairs, immediately charged that O'Connor aimed at a comeback in Irish politics by means of a reconciliation with his old foe, $\mathrm{O}^{\prime}$ Connell, jettisoning the Chartists in the process. ${ }^{54}$ O'Connor countered by claiming that the convention had failed because of the pusillanimity of middle class members such as Whittle. He also insisted that The Champion

spring of 1839 at which O'Connor was to be a speaker: Public Record Office, Home Office $40 / 43,234$.

${ }^{49}$ The Champion, 10 March, 12 May 1839.

${ }^{50}$ Back at the time of Cobbett's death in June 1835 , O'Connor ran for his seat at Oldham in competition with John M. Cobbett. In the campaigning, Whittle provided the younger Cobbett with unfavorable data on O'Connor's Irish M.P. record: Manchester Guardian, 4 July 1835 . In the 1839 O'Connor-Whittle dispute, this incident was revived: The Champion, I 3 October, 17 November 1839; Northern Star, 2, 23 , November 1839 .

${ }^{51}$ Typically, Robert Lowery, too, grew very suspicious of O'Connor as the result of the $1838-39$ events: Harrison and Hollis, 'Chartism . . . and . . Lowery'. English Historical Review, LXXXII (1967), 515.

${ }^{52}$ The Champion, 15, 29 September 1839.

${ }^{53}$ Ibid., I3, 20 October 1839.

${ }^{54}$ Ibid., 1 3, 20 October 1839. 
editor, who had accused him of being a covert O'Connellite as an Irish M.P. in 1835 , had misrepresented his record..$^{55}$ At this point in the dispute, O'Connor returned from Ireland. Almost simultaneously, the foredoomed Newport, Wales Chartist uprising occurred. To Whittle this was the last straw. His contention that loud talk might induce an ill-conceived rising had been tragically demonstrated. Therefore he bitterly denounced O'Connor for having indirectly produced it, and, worse, absconding to Ireland to try to evade the consequences. ${ }^{56}$ The dispute between the two lingered on into I 840. On Whittle's side it ended when The Champion, as part of the post-I 839 Chartist eclipse, faded out in April. As for O'Connor, he kept it up in the pages of the Northern Star awhile longer. ${ }^{57}$

With the demise of The Champion, Whittle dropped out of the Chartist world. He must have done so in a mood of considerable bitterness. Politically, not a one of the hopes that he had entertained since I 830 had been realized. Worse, as a concomitant of mass protest, the workers had raised up an irresponsible demagogue - as Whittle saw him-in the person of Feargus O'Connor. They showed every sign of continued attachment to their hero. Personally, his life had gone no better. He had had the opportunity to edit three papers. In the case of the first one, though the paper stayed alive, his editorship did not. With regard to the latter two, the journals themselves had collapsed. It was not the Northern Star that failed, but The Champion. Never again did Whittle's name turn up in connection with a Chartist function.

Not long after the hectic events of $1838-40$, Whittle obtained an executive position with Guiness Brewery. He served in this capacity for some thirty years. ${ }^{58}$ In old age, he retired to Douglas, Isle of Man. ${ }^{59}$ Having divided his life between the islands of Ireland and England, Whittle, fittingly, died on the isle between them, January I0, $1874 .^{60}$ He had been all but completely forgotten.

55 Northern Star, 2 I September, 2, 9, 23 November 1839.

${ }_{56}$ The Champion, 17 November 1839.

57 The last issue of The Champion was 26 April 1840. O'Connor kept the quarrel alive in the Northern Star until I 6 May 1840.

${ }^{58}$ How Whittle during his business career found an outlet for his intellectual interest can only be a matter of conjecture. Perhaps he travelled and translated. In British Museum General Catalogue of Printed Books (1965 ed.) Vol. 257 c.l., James Whittle (tr. from the German), $A$ Visit to Belgrade (London, 1854) appears. However, whether this is the correct Whittle is by today impossible to determine: Edward Miller, Assistant Keeper, The British State Paper Room, British Museum, to author, io August 1972.

${ }^{59}$ Manchester Guardian, 2 I January 1874.

${ }^{60}$ Copy of death certificate, General Registry, Isle of Man, to author, 27 August 1975; The Isle of Man Times and Advertiser, 17 January 1874. 